\title{
Chapter 6 \\ Ideology, Spatial Planning, and Rural Schools: From Interwar to Communist Hungary
}

\author{
Ferenc Gyuris
}

The development of education systems has always been strongly linked to dominating ideologies and their notions about the structure and functioning of society. What is a desirable spatial distribution of physical infrastructures of education, such as school buildings and teaching equipment? What sort of knowledge and norms and value systems are teachers expected to convey to their pupils and students? What role should formal institutions play in education, and where is the place for informal learning? Who is to cover the related expenses? One can answer these questions in many different ways, and societies with various ideological stances might have different preferences even if their material realities (such as the physical geography of the given area, technologies of construction, technically accessible equipment, and characteristics of the urban network) are similar. The outcomes of such varied preferences for ideological reasons might be the most visible in geographical settings which undergo significant political ruptures in a given period, especially if political structures are centralized and relatively few actors have the actual power to shape the education system.

In this chapter, I focus on Hungary between the World Wars and during the communist period; both timespans provide remarkable evidence for how changing ideologies impact the education system. My main interests are twofold. On the one hand, I am interested in the interwar nationalist-conservative regime, which considered education an essential means of assuring cultural advantage and the "revival" of the nation after the 1920 Trianon Peace Treaty, an outcome of the post-World War I peace negotiations that forced the country to surrender more than two thirds of its territory and roughly one third of its native Hungarian population. On the other hand, I want to reveal how official ideologies in the Communist system emerging after World War II influenced the improvement of the education system. I will

\footnotetext{
F. Gyuris $(\bowtie)$

Department of Regional Science, Institute of Geography and Earth Sciences,

Eötvös Loránd University (ELTE), Budapest, Hungary

e-mail: gyurisf@caesar.elte.hu
} 
employ small rural schools as key loci of basic education in what are mostly peripheral regions as a case study to identify the major ideological shifts and the way these played out in everyday practice. In doing so, my goal is also to provide a more sophisticated view of both periods and to underline that neither the interwar period nor the communist epoch were profoundly homogenous (including in terms of education), especially for the changing power geometries of international political and economic relations into which Hungary was embedded. In addition, I will argue that some continuities existed even in times of remarkable political changes.

\section{Literacy, Education, and the "Torch of Civilization": A Brief History}

In the early twenty-first century, a broad consensus exists in most parts of the world that the ability to read and write is fundamental knowledge that should be accessible for every human being. Likewise, basic education as a framework for spreading literacy and as the main mediator of various sorts of knowledge commonly regarded as essential is often seen as a merit good (Musgrave, 1957), which everyone has the right to. These views were not given a priori in human history; instead, they are socially constructed outcomes of a perpetually changing political discourse. They emerged only when some specific social circumstances were already given and they met the interests of both the "power elites" (Mills, 1956) and the broad masses (Titze, 2006). As Meusburger (1998, 2015) and Schriewer and Nóvoa (2001) stress, teaching everyone to read and write by providing them with a basic education became a fundamental European goal hundreds of years after the Reformation and the reformers' attempts to enable people to read the Bible. It accompanied the emergence of modern nation states, the politicians of which expected their citizens to internalize national ideology, and the rapidly increasing demand for a skilled workforce during the Industrial Revolution.

Yet, as soon as striving for universal literacy and education became the norm in many parts of Europe, statistics reporting on the advance of the process gained political relevance. Countries that proved more efficient in improving these numbers were increasingly considered more "civilized" and "cultured," and thus "superior," and to possess the right and duty to spread advanced civilization. ${ }^{1}$ This became a central argument to justify the colonial attempts of European great powers as a mission civilisatrice or civilizing mission, to "help" "inferior," "savage," and "barbarian" peoples gain a level of culture they have failed to reach so far (Bullard, 2000; Butlin, 2009; Conklin, 1997) and may remain "unable" to achieve on their own in the future, due to detrimental factors such as "unfavorable" climatic conditions

\footnotetext{
${ }^{1}$ Meanwhile, people with little or no formal education in countries with otherwise relatively high literacy and education standards were often othered as "immoral," "criminal," or "vicious," in France (Dupin, 1826), the United Kingdom (Booth, 1902-1903), as well as North America (Bateman, 2001; Hunt, 2002).
} 


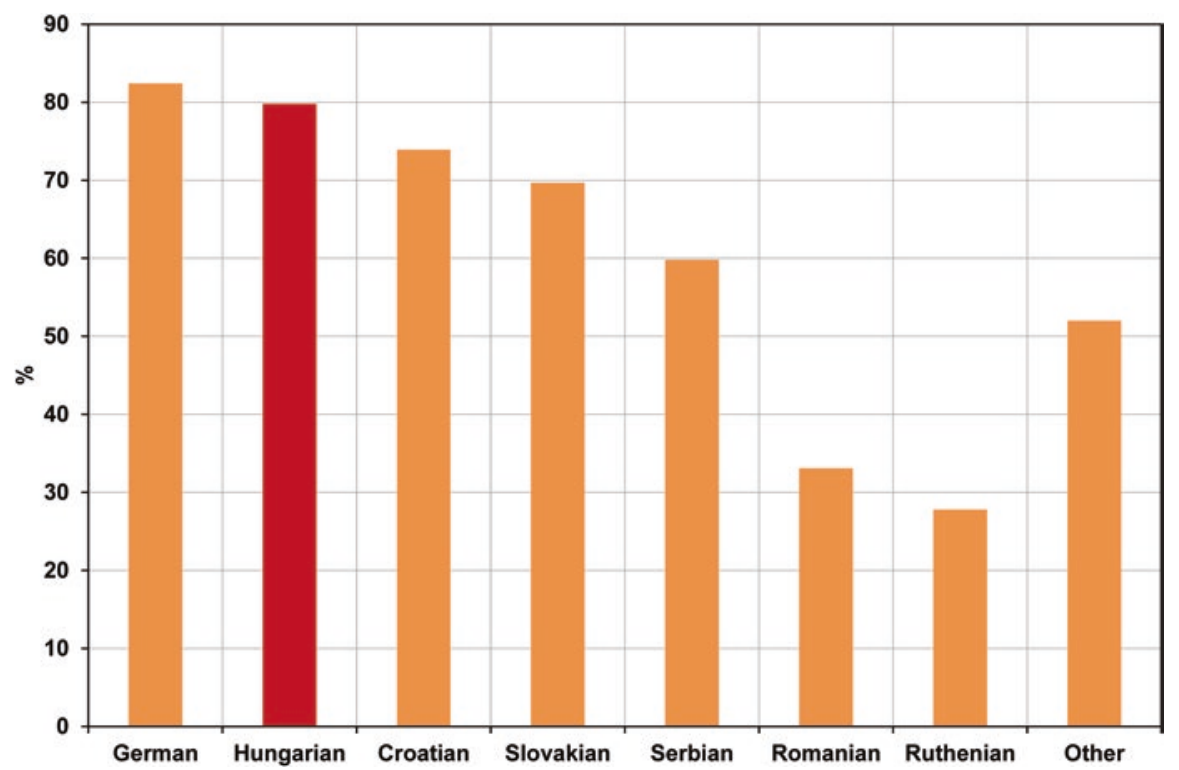

Fig. 6.1 Literacy rates of inhabitants over 6 years of age by native language. Adapted from $A$ Magyar Szent Korona országainak 1910. évi népszámlálása. Hatodik rész. Végeredmények összefoglalása [The 1910 Census of the lands of the Holy Crown of Hungary. Vol. 6. Summary of final results] (p. II/179), by the Hungarian Central Statistical Office, 1920, Budapest: Athenaeum. Copyright 1920 by the Hungarian Central Statistical Office. Adapted with permission

(Livingstone, 2002, 2011). Political struggles in Europe were subject to similar interpretations. In World War I, countries on both sides claimed the distinction of being "more civilized" for themselves, portraying themselves as fighting against the "less civilized" Other. This language also infiltrated the official documents of the postwar peace negotiations and their academic commentaries in the countries concerned (Treaty of Peace with Germany, 1919; Schroeder-Gudehus, 2014).

Hungary was no exception. After the 1867 compromise with Austria, which guaranteed Hungary equal rights and sovereignty in the empire, a massive project of nation-building, similar to those in other parts of the continent, started in the Hungarian part. Therefore, political and academic statements on disparities of education predominantly focused on the ethnic aspect. Their authors emphasized that the literacy rates of Hungarian native speakers over 6 years of age were higher than those of any minority inhabitants, with the exception of German native speakers, to whom both Austrians and Hungarians traditionally attributed an advanced culture (see Fig. 6.1).

Such trends brought into being the notion of Hungarian cultural advantage, which claimed that Hungarians possessed a "superior" level of culture, compared both to the country's minorities as well as to neighboring countries to the east, 
southeast, and south. ${ }^{2}$ Given that the literacy rates of Romanian and Serbian native speakers in Hungary were still higher than in Romania and Serbia, the dominant view of the native Hungarian political and academic elite was that these minority groups, although "less civilized" than the Hungarians, still managed to gain "more culture" as inhabitants of the Kingdom of Hungary. They claimed this vindicated the state of Hungary as a more efficient framework to "civilize" people than Romania or Serbia, and thus a framework that should be kept in the future to the benefit of the entire European civilization. One of the most detailed explanations of this argument was published in the 1918 article "A Magyar Földrajzi Társaság szózata a világ Földrajzi Társaságaihoz" (Manifesto of the Hungarian Geographical Society to the Geographical Societies of the World, 1918), published anonymously but actually written by Pál Teleki (Fodor, 2006), the most influential geographer of the interwar period, who also served as Prime Minister for two terms (1920-1921 and 19391941). The manifesto's explicit aim was to explain the territorial interests of Hungary and present the arguments of Hungarian geographers for an international public before the peace negotiations.

The concept of cultural advantage also emerged in a number of works from other authors, especially with regard to Hungarian economic and political interests in the Balkan Peninsula (Havass, 1912, 1913). Jenö Cholnoky, then vice president (and from 1914 onwards president) of the Hungarian Geographical Society, referred to this as an area that Hungary "could have made use of ... just like from a colony" (Cholnoky, 1912, p. 3). A 1916 article in Földrajzi Közlemények [Geographical Review], the official journal of the Hungarian Geographical Society, argued that "we and our allies have the task ... to bring the lighting torch of culture to the inhabitants" of Greater Serbia (Kemény, 1916, p. 107). The head of the Hungarian delegation to the peace conference after World War I, Count Albert Apponyi, also referred to disparities of education and culture as a main argument for maintaining the boundaries of Hungary instead of accepting the territorial claims of Romanian, Serbian, Czech, and Slovakian political and intellectual circles. As he put it in 1920:

I believe that, from the point of view of the great interests of humankind, one can observe
neither indifferently nor with satisfaction the national hegemony being vested in nations
that, even if holding up the best hopes for the future, still stand at a low level of culture.
(Apponyi quoted in Romsics, 2007, p. 170)

In this social and political context, other aspects of education inequalities were also interpreted in conceptual frameworks oriented around ethnicity. Hungarian geographers claimed that regional disparities of literacy rates-which in 1910 ranged from $95.0 \%$ in the town of Sopron close to the Austrian border to $26.8 \%$ in Máramaros County in the northeast and $25.1 \%$ in Lika Krbava county in the southwestern Croatian districts-reflected the different ethnic and linguistic structure of the population in various parts of country (see Fig. 6.2).

\footnotetext{
${ }^{2}$ This sort of thinking was pervasive across Europe, even in political discourses. As Teleki (1936) ironically underscored: "We should just ask the peoples of Europe about their neighbors-almost each of them will consider its Eastern neighbor barbarian, or at least not a European on a par with itself" (p. 360).
} 


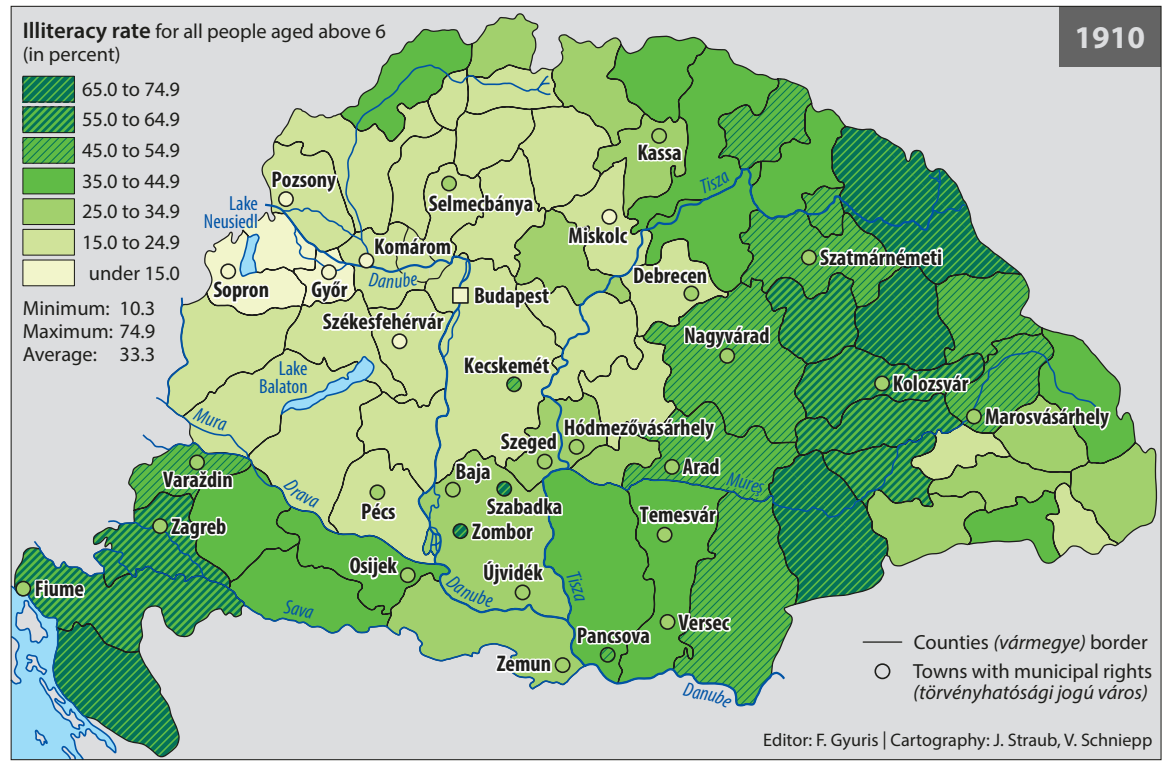

Fig. 6.2 Illiteracy rates of the population over 6 years of age by county in 1910. Reprinted from $A$ Magyar Szent Korona országainak 1910. évi népszámlálása. Hatodik rész. Végeredmények összefoglalása [The 1910 Census of the lands of the Holy Crown of Hungary. Vol. 6. Summary of final results] (pp. 166-169), by the Hungarian Central Statistical Office, 1920, Budapest: Athenaeum. Copyright 1920 of the Hungarian Central Statistical Office. Cartography by V. Schniepp and J. Straub

Arguments about the claimed cultural advantage of the Hungarian people and the civilizing mission of Hungary, however, fell short of convincing the representatives of the peace negotiations' winners to maintain the country's territorial integrity. Not only did the Austro-Hungarian Empire collapse a few months after the end of the war, but the 1920 Trianon Peace Treaty resulted in devastating territorial losses for Hungary, equaling roughly two thirds of the country's area.

\section{After the Trianon Trauma of 1920: Education as Defending the Homeland}

\section{Ideology and Political Goals}

The Trianon trauma shocked Hungarian society, and lead the authoritarian nationalist-conservative regime that was leading the country in the interwar period to define territorial revision as its ultimate goal. The corresponding development of the education system became the task of Count Kuno Klebelsberg, a veteran of cultural politics, who had already served the governments as Secretary of State between 
Fig. 6.3 Count Kuno Klebelsberg, Minister of Religion and Education between 1922 and 1931 . Reprinted from Hungarian National Museum,

Historical Photographic Collection, Ltsz. 1659/1957 fk. Copyright 1900s by the Hungarian National Museum. Reprinted with permission

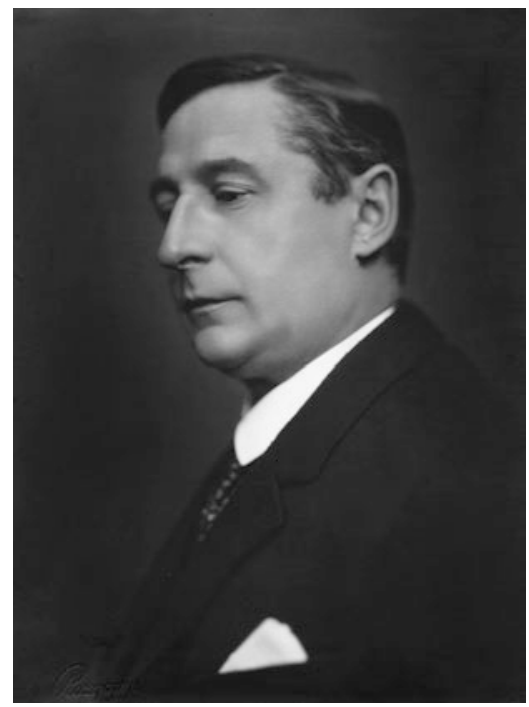

1914 and 1917 (see Fig. 6.3) (Huszti, 1942). Klebelsberg made the notion of cultural advantage a cornerstone of his political program, although in a remarkably different meaning to how it was broadly used in the 1910s. Instead of referring to the cultural "superiority" of the Hungarian people as a condition that was already achieved and provided justification for territorial interests per se, he claimed that cultural advantage was a key precondition for international actors to accept Hungary's claims, but one that had not yet been achieved, and for which much had to be done. Klebelsberg underscored the remarkable gap in education statistics between Hungary and the most powerful winners of the war. He did this in a period when Hungary's illiteracy rate for the population aged over 15 was still $13.4 \%$, whereas it was $8.2 \%$ in France, $7.8 \%$ in Belgium, and only $6.0 \%$ in the United States (UNESCO, 1953, pp. 200-213). Moreover, he warned that the neighboring countries, against which Hungary had territorial claims, might soon improve the education of their citizens and surpass Hungary (Klebelsberg, 1927).

Klebelsberg's goal was therefore a massive development of education, including all levels and forms. As he put it, also with regard to the severe military restrictions issued for Hungary in the peace treaty: "Today it is mainly not the sword, but culture that can defend the Hungarian homeland and make it great again" (Klebelsberg, 1927, p. 604). Therefore, as he emphasized at a speech in Stockholm in 1930 on the "calling of Hungary in world history," "we now consider the ministry of education as the ministry of defending the homeland" (Klebelsberg, 1931, p. 182).

In Klebelsberg's vision, educational development had to incorporate both elite and mass education. As he phrased it: "Thousands of leaders at European standards should be placed on the top of national production, and millions of masses with high moral and mental culture in the service of [it]" (Klebelsberg quoted in Glatz, 1990, pp. 444-446). Whereas the former goal served the establishment of an efficient 
diplomacy and economy, to "advertise the Hungarian truth to the nations of the world with the word of mind" (Klebelsberg, 1930, p. 92), Klebelsberg considered mass education as a prerequisite for an efficiently functioning economic and political system. In this sense, he envisaged a modern "economic competition of the nations" (Klebelsberg, 1928, p. 209) where "the masses of Hungarian workers" should stand their ground in "the competition of working masses of more educated nations" (Klebelsberg, 1927, p. 318).

Furthermore, he considered mass education a key to "social evolution." In the context of the 1920s, with a multiparty parliament but a conservative authoritarian framework in the style of the nineteenth century, the interwar regime consciously wanted to prevent the lower social classes from gaining influence on political decisions (Ablonczy, 2009). Count István Bethlen, the elitist conservative Prime Minister between 1921 and 1931, considered mass democracy "the blind rule of the raw masses," which he contrasted to "real" and "healthy democratic development ... ensuring the leadership for intelligent classes" (Bethlen, 1933, pp. 158-159). Hence, the 1922 election law reduced the share of elective citizens above 24 years from $75 \%$ to $58 \%$ and provided a secret ballot for only one fifth of the voters (Romsics, 2010). Klebelsberg also claimed that educating the masses was necessary to prepare people for political democracy, for which many of them were considered "immature." He ironically underscored that "[u]niversal secret suffrage operates with ballots. I would love to see how one can work with ballots with around a million illiterate voters" (Klebelsberg, 1928, p. 206). "Political democracy will become a benefit for the peoples only if prepared by real cultural democracy" (Klebelsberg, 1929 , p. 168).

The Klebelsbergian concept of cultural advantage thus urged a large-scale development of the entire system of education, which was a highly expensive project, especially considering Hungary's war casualties, the reparations declared in the peace treaty, and the loan the country had to take from the League of Nations in 1924 in order to stabilize its economy after a period of extreme inflation. Klebelsberg, however, had the ears of Prime Minister Count István Bethlen, who had been his friend and political ally for a long time. Bethlen provided stable support to Klebelsberg's plans. As a result, the Ministry of Religion and Education's share of the government budget doubled from 4.54\% in the financial year of 1922/1923 to 9.15\% in 1924/1925, and exceeded 10\% after 1928/1929 (Ujváry, 2009, p. 400). These values were twice as high as between 1900 and 1913 (Romsics, 2010), and meant that Klebelsberg's ministry had become the largest one in terms of funding (Ujváry, 2009). The special position of education and culture was also symbolized by the fact that Bethlen was often deputized by Klebelsberg at government meetings and official events he could not attend (Ujváry, 2014). 


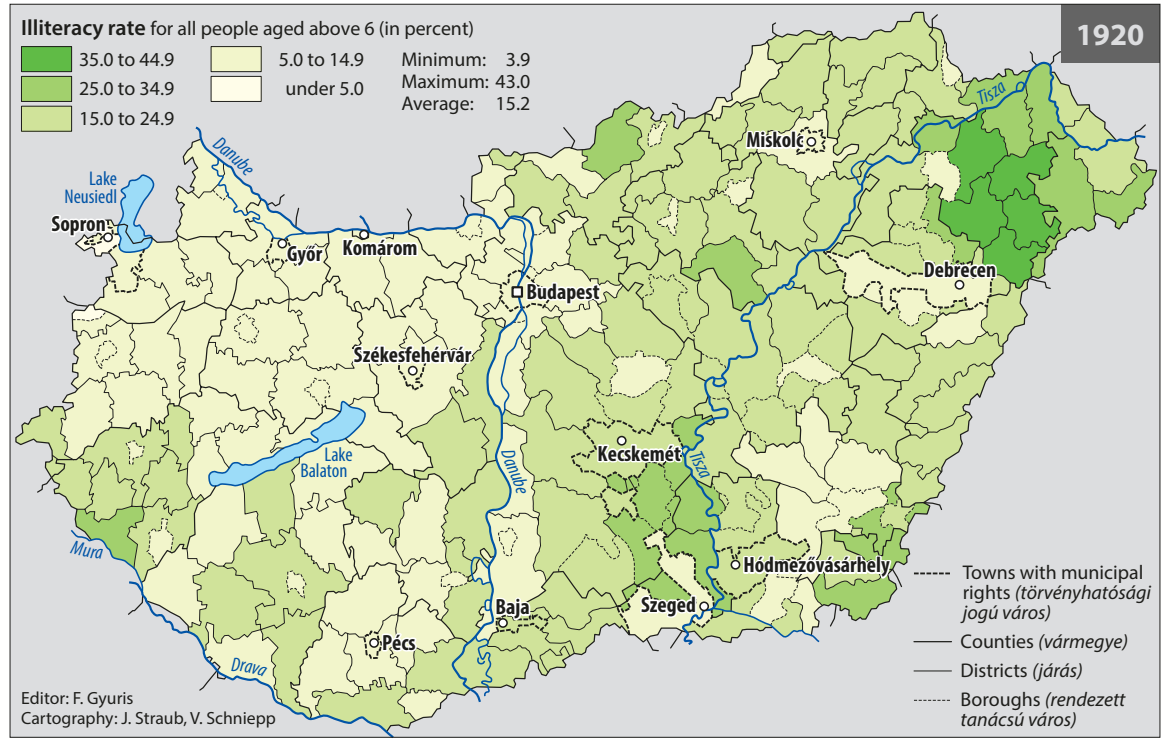

Fig. 6.4 Illiteracy rates of inhabitants over 6 years of age by district in 1920. Adapted from the Hungarian Central Statistical Office, 1929, p. II/138. Copyright 1929 by the Hungarian Central Statistical Office. Adapted with permission. Cartography by V. Schniepp and J. Straub

\section{Changing Geographies of the School System}

The implementation of the plans on mass education had to respond to the strongly geographical nature of the problems to be cured. Contrary to the ethnicity-oriented interpretation of education disparities before the peace treaty, post-Trianon Hungary also had remarkable inequalities of literacy, such as spatial ones, although $89.6 \%$ of the population had Hungarian as native language in 1920 (KSH, 1929, p. II/39). Still, illiteracy rates at the district level (the second administrative level below the national one) varied between 3.9\% (in the town of Sopron) and a remarkable 43.0\% in Ligetalja District in the northeastern county of Szabolcs (see Fig. 6.4). Moreover, several districts had values above $25 \%$.

This problem had its roots in the geography of the settlement network. Compulsory education was introduced in Hungary in 1868 and school attendance had been free of charge since 1908. In rural areas with small villages, however, the number of school buildings as well as their spatial distribution was insufficient to truly provide all children with access. Hence, in the school-year of 1920/1921, $17.2 \%$ of school-age children did not attend formal education (Szabó, 2007, p. 41). The specific settlement type of scattered farms (tanya in Hungarian) faced especially strong challenges. The history of these farms goes back to the sixteenth and seventeenth centuries, when Hungary was in the contact zone of the expanding Ottoman Empire and the Habsburg Empire. Ongoing conflicts in the frontier devastated a considerable part of the villages in the Hungarian Great Plains, and 


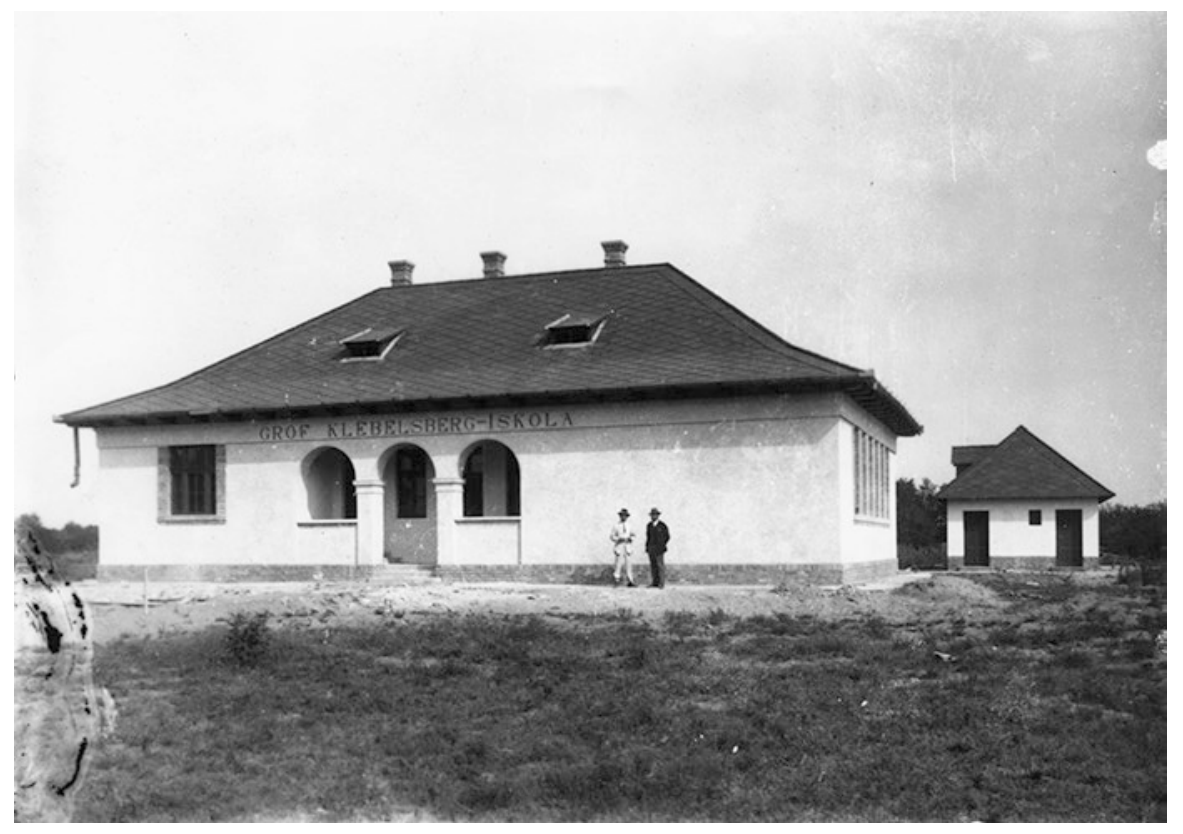

Fig. 6.5 New rural school in Domaszék during the 1920s, named after Klebelsberg. Reprinted from Hungarian National Museum, Historical Photographic Collection, Ltsz. 82.772. Copyright 1920 s by the Hungarian National Museum. Reprinted with permission

Ottoman troops subjected most towns to lootings. A remarkable exception were the so-called khas towns, which were directly subordinated to the sultan even in terms of paying tax and thus protected from raids. This distinction made between towns caused many people to flee from rural areas, now mostly deserted, to khas towns. After the end of the Ottoman occupation, agricultural production radically increased, and many urban dwellers erected small buildings in their plots, which were often far from the town, and used them during the months of intensive agricultural work. From the late nineteenth century onwards, however, a rapidly growing number of people, mostly belonging to the poorest strata of agricultural population, moved out to scattered farms, which thus became permanent settlements (Beluszky, 2003). In 1930, roughly 800,000 people, almost one tenth of the country's population, lived on scattered farms (Becsei, 1996, p. 46). The physical infrastructure was poor, however, and in many cases neither the landowners nor the nearby villages provided the children of domestic workers on large agricultural estates with education (Pornói, 1995).

In order to cope with this situation, Klebelsberg's ministry launched a national program of building "people's schools" in 1926. By 1930, the ministry had established 5000 new elementary schoolrooms and flats for teachers. The spatial focus was rural areas with small villages and scattered farms. Thus, two thirds of the new physical infrastructures-including 2315 schoolrooms and 1130 flats for teachers- 
were installed in scattered farm regions (Zátonyi, 2006, p. 49) (see Fig. 6.5). It speaks volumes about the scale of the project that between 1890 and 1913, the last two dozen peaceful years before WWI, the number of newly opened elementary schools in the entire country was only 302 (Romsics, 2010).

Since Klebelsberg considered efforts to promote cultural advantage a national project, the government expected all actors concerned to contribute to the costs. Therefore, the education system was financially based on funding from an array of contributors. The expenses of the people's schools program were mostly covered by the state, but some other actors were also expected to take part. In the academic year of $1937 / 1938$, out of the 7376 elementary schools in Hungary, $18.7 \%$ was maintained by the state, $12.0 \%$ by localities, $2.6 \%$ by associations and private supporters, and $66.7 \%$ by various churches $(41.4 \%$ by the Roman Catholic Church, $15.6 \%$ by the Calvinist Church, $5.7 \%$ by the Lutheran Church, and $4.0 \%$ by other churches including the Jewish community) (Szabó, 2007, p. 45).

In fact, both decentralized financial schemes and limits on the resource side maintained certain inequalities in the system. Parochial schools were strongly independent from the state as well as higher administrative levels of the inner hierarchy of the church. They were managed by the parishes, whereas the share of state transfers in their income was usually less than $45 \%$. Differences were even larger for secular schools, where localities covered $81.8 \%$ of all expenditures, and state transfers constituted only $18.2 \%$ (based on data from Nagy, 2005, p. 120). Hence, more affluent parishes and localities could achieve a considerably higher standard of education. Besides, in 1936/1937 only $9.1 \%$ of the elementary schools were fully divided, that is, exclusively running single-grade classes, with one teacher for every class. Almost half (45.2\%) were not divided at all, meaning that they had multigrade classes only, where a single teacher was in charge of all six classes of compulsory elementary education, and these six classes were educated in one room (Zátonyi, 2006). This was a moderate improvement compared to corresponding values in 1920/1921 - 6.6\% and 50.1\%, respectively-(Pornói, 1995, p. 317). However, as the institutions with divided classes were larger, only $19 \%$ of the pupils learnt in undivided schools in 1924/1925, and 18\% in 1930/1931 (Romsics, 2010, p. 177). ${ }^{3}$

Another characteristic outcome was that school development programs seemed to sustain a dual-track system in the sense of social mobility. Secondary and higher education remained - and was intended to remain — dominated by children from the middle and higher classes. Elementary education also hid considerable unevenness in the standard of education. The number of teaching hours per week according to the official curricula increased in divided schools from 21 in the first class to 30 in the fifth and sixth classes. For undivided schools, the corresponding values were between 7.5 and 10. The curricula's content also differed, for undivided schools

\footnotetext{
${ }^{3}$ Although in more recent literature several authors refer to the potential advantages of undivided schools, such as heterogeneity or that older pupils can contribute to teaching younger ones (e.g., Freytag, Jahnke, \& Kramer, 2015; Kramer, 1993; Meusburger, 1998), in the Hungarian context of the 1920s and 1930s undivided schools were commonly regarded as a lower-standard alternative to divided schools.
} 
mainly focused on mediating knowledge the pupils could utilize in their everyday life while helping their family, instead of preparing them for higher stages of education (Zátonyi, 2006). This was in general more in line with nineteenth century Western European views that education should serve social stability instead of social mobility (Meusburger, 1998, pp. 275-276). Such notions were also in concert with the political concept of the Bethlen government and the entire interwar period, a main feature of which was low social mobility compared to Western European countries (Romsics, 2010).

Yet, as Ujváry (2014) underlines, Klebelsberg indeed made remarkable efforts to decrease disparities in education and to make possible in the long run what he called "cultural" and "political democracy." He considered the entire authoritarian political framework of the day only temporarily acceptable, although the same was not true for several other leading politicians, including some of Klebelsberg's fellow ministers. He also urged the introduction of 8-year elementary schools instead of 6-year ones, although the related law was issued only in 1940, and a nationwide shift to the new system did not take place before the post-World War II period (Romsics, 2010). Moreover, the thousands of new elementary schools meant an actual and radical improvement in access to formal education in scattered farm districts. Social consequences were also very positive and in line with intended goals: The national illiteracy rate decreased from $15.2 \%$ in 1920 to $7.6 \%$ in 1941 , a value almost on a par with what was typical in Western European countries (Ujváry, 2009, p. 393). Klebelsberg also put emphasis on educating those generations already above school age, for example by establishing more than 1500 "people's libraries" and 1580 "people's houses" or "houses of culture," which provided cultural and popular science events for rural dwellers (Romsics, 2010). Given that secondary and higher education as well as scientific research also gained massive support in the meantime, remarkable investments in elementary education, and mostly in rural regions, were running parallel with developments at higher levels of education in large urban centers.

Klebelsberg's projects and their outcomes gained recognition from influential foreign actors in the politics of education and culture, too (Ujváry, 2009). One of these actors was Carl Heinrich Becker, Prussia's Minister for Culture (1921 and 1925-1930) and a main reformer of education in the Weimar Republic (Ujváry, 2006). Friedrich Schmidt-Ott, a predecessor of Becker at the ministry and President of the 1920-founded Emergency Association of German Science (Notgemeinschaft der Deutschen Wissenschaft), who was fired from his position by the Nazis in 1934 (Hentschel \& Hentschel, 1996), also praised Klebelsberg and his efforts in his memoirs (Schmidt-Ott, 1952). ${ }^{4}$

\footnotetext{
${ }^{4}$ In the 1920s, both Becker and Schmidt-Ott paid visits to Hungary (Ujváry, 2009).
} 
Fig. 6.6 Bálint Hóman, Minister of Religion and Education from 1932 to 1938 and 1939 to 1942. Reprinted from Hungarian National Museum,

Historical Photographic Collection, Ltsz. 1563/1956 fk. Copyright 1930s by the Hungarian National Museum.

Reprinted with permission

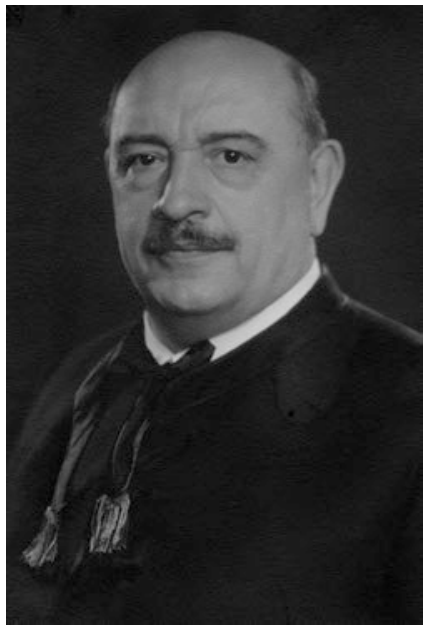

\section{Changing Circumstances from the Early 1930s: People's Schools Versus "Overproduction of the Intelligentsia"}

In the years of the Great Depression, the Bethlen government resigned in 1931. This put an end to Klebelsberg's term as well, who died one year later. Yet, personal stability at the top of education and cultural politics remained characteristic for the coming years. After Klebelsberg's 7-year term, his close colleague and the already renowned historian Bálint Hóman, whom Klebelsberg himself had desired as his successor, was the minister from 1932 to 1938 as well as 1939 to 1942 (see Fig. 6.6). In some ways, Hóman followed his predecessor's policies. He adopted the notion of cultural advantage, secured the budget of the ministry, ${ }^{5}$ and launched a new people's schools construction program in 1934 with a focus on rural areas, which resulted in more than 1800 new school units and the renovation of several others by 1940 (Ujváry, 2009).

Another similarity was the sort of criticism Klebelsberg and Hóman permanently faced. Many contemporaries, including politicians of the Ministry of Finance, considered their projects a waste of money. Protests by local actors, who were now expected to contribute to the costs of education programs, also took place, for example from the side of landlords who did not want to spend money on scattered farm schools. Moreover, Dezső Szabó, an influential populist writer of the interwar period, criticized the "German consanguinity" of both Klebelsberg and Hóman.

\footnotetext{
${ }^{5}$ The Ministry of Religion and Education's share of the government budget kept increasing, from around $10 \%$ to $13 \%$ in 1940, although this still meant some decrease in nominal terms, because the total budget declined after the Depression (Ujváry, 2009, p. 400).
} 
The "ministry of Hungarian culture," he argued, had become a "German ministry" (Szabó, 1937, p. 3). ${ }^{6}$

However, the two minister's concepts also differed in some important ways. Hóman considered Klebelsberg's cultural program "oversized," especially with regard to higher education, which he believed to fuel "the overproduction of the intelligentsia” (Hóman, 1938, p. 540). In contrast, Hóman's initiatives clearly aimed to increase social mobility and enable "talents from below" to catch up with and gain access to middle-class occupations, and he launched various programs to financially support the secondary or even tertiary education of outstanding pupils from poor families (Ujváry, 2009). As a result, people's education-including all primary schools and primary-level education programs for adults - gained an increasing share of the ministry's budget, rising from the typical $32 \%$ to $35 \%$ of the 1920 s to around 40\%, and later to roughly 50\% (Hóman, 1942, pp. 180-181). As Hóman put it in a speech in 1938, "a school teacher is more important than a university lecturer, because national culture depends" on the former (Hóman quoted in Joó, 2006, p. 15).

These changes were inseparable from Hungary's evolving political atmosphere, which again was strongly influenced by shifting power relations in international politics. After the Nazi takeover in Germany in 1933, the Hungarian political leadership, like considerable parts of Hungarian society, increasingly regarded Germany as the country which might provide the most support to Hungary's revisionary attempts. This led to increasing cooperation with Germany compared to the $1920 \mathrm{~s}$ and the government of Bethlen, who was a committed supporter of British orientation. Modernist methods gained more legitimacy as well. Hóman's initiatives were accompanied by a tendentious centralization of education, whose implementers were attempting to reduce unevenness (including geographical disparities) in the school system on the one hand, while reducing the impact of local communities on their schools and increasingly subordinating them to state-level decision-making on the other (Nagy, 2011).

Right-wing radicalism and antisemitism were also gradually growing, which resulted in firm attempts to reduce the share of Jewish people in higher education and occupations requiring a university degree (Ungváry, 2016). Therefore, as Nagy (2004) also emphasizes, the concept of the "overproduction of the intelligentsia" was strongly intertwined with anti-Semitic attempts, and the notion of "talents from below" (p. 253) was not independent from the willingness to achieve ethno-political changes in culture and the economy. In Hungary, a numerus clausus law was issued as early as 1920 with the aim of preventing ethnic groups defined as non-Hungarian from being overrepresented in higher education compared to their total population share. In 1928, pressure from the League of Nations forced the Bethlen government to change this law. The ethnic quota was eliminated and replaced by an occupation quota, which partly improved the actual opportunities of Jewish students and constituted a symbolically important move against far-right political attempts. However, Bethlen consciously tried to reverse this effect, while partially substituting

\footnotetext{
${ }^{6}$ Klebelsberg's family was partly of Tyrolian descent and Hóman had some German ancestors. In fact, both of them were born in Hungary to families with strong Hungarian identities, and with several ancestors from the Hungarian nobility (Ujváry, 2009).
} 
open antisemitism with a latent form in social politics (Paksa, 2014). During Hóman's term in the 1930s, such radical voices were much stronger, however, and Hóman himself was openly antisemitic. Moreover, although he personally did not feel much sympathy for the German orientation, he was convinced that Hungary could only choose between Germany and the Soviet Union. He therefore supported all three anti-Jewish laws in 1938, 1939, and 1941, and did not resign from his parliament mandate either after the German occupation of Hungary in March 1944 or the coup of the extreme-right Arrow Cross Party in October 1944 (Ujváry, 2009).

\section{After the Communist Turn: Stalinist Modernization and the Village as "Feudal Vestige"}

\section{Attempts to Make a Clean Slate of the Past}

World War II, which Hungary entered in 1941, left the country in ruins. Until 1945, roughly 900,000 citizens were killed and approximately two fifths of the national economic wealth was destroyed (Romsics, 2010). The country became part of the Soviet occupation zone, although in the first years a multiparty regime was allowed to function, until a Stalinist dictatorship was established in 1948. Education also suffered severe losses, including school buildings, teachers, and equipment. Multiparty governments therefore had to focus on restoration and did not have the resources for massive development. Yet they still carried out many institutional reforms that had been planned as early as the interwar period. For example, although Klebelsberg had already propagated the introduction of the 8-year primary school system, its actual implementation proceeded very slowly. After 1945, however, the reform sped up and was completed the end of the decade (Zátonyi, 2006). The number of new teachers also grew rapidly, although at the cost of shorter teacher training programs and the resulting lower standards (Romsics, 2010). In these years, in politics in general and in education policies in particular, most steps were aimed at the democratization of education and increasing social mobility, which most parties tried to achieve by copying Western examples.

After the Stalinist turn, however, the underlying ideology, the notion of planning and education, and the role of rural schools underwent radical changes. The Communist regime was, on the one hand, interested in providing equal access to education at the same standard. This was firstly because party leaders considered some basic education a necessary prerequisite for building communism. Just like in the Soviet Union, where the top leadership launched a program for the "liquidation of illiteracy" as early as 1919 (Downing, 1988), Hungarian communists were aware that the modern large-scale industry they envisaged could only function on the basis of a sufficiently educated workforce. What they actually judged erroneously was, as Meusburger (1998, pp. 93-96) underscores, that increasing division of labor did not reduce the need for highly qualified experts in efficiently organizing labor. Hence, 
providing primary education to all and some secondary education to many could only complement but not substitute top-notch expertise. Second, the Communist leaders realized the crucial importance of school education in controlling society and that schoolroom spaces were an optimal arena to create the new "socialist type of human" (Sáska, 2005, p. 85). Third, the Communist regime drew great propaganda value from providing equality of chances in education (Kovács, 2003), as it could advertise the "just" character and moral superiority over capitalism that it claimed.

The new political and economic system, however, also had some inherent features and fundamental ideological as well as practical concepts that conflicted with the aforementioned views. Communism presented itself as "more advanced" than capitalism for cancelling the unnecessary waste of resources resulting from the competition of private actors and ensuring a higher level of cost efficiency. Moreover, given the considerable economic handicap of the Eastern Bloc compared to the United States and its allies, the system fundamentally focused on investing as many resources as possible in economic growth and modernization. The outcome was that Communist regimes tended to notoriously underfinance sectors and occupations considered to be "nonproductive" in the narrow material sense, such as those based on nonmanual work (Gyuris, 2014a). Besides, all prominent Stalinist politicians regarded centralization, or "democratic centralism" in the Leninist vocabulary, as an essential prerequisite for efficient control, orderliness, and economies of scale. They believed that a successful implementation of the commands from above, the "vanguard party," was only possible if these were not distorted by any potentially ill-informed autonomous actors at the lower levels.

The outcome of these controversies was a virtually profound nationalization of the school system in 1948 (Kelemen, 2003), including the dispossession of physical structures, the collectivization of the production and retail of textbooks and equipment, and an extreme centralization and Stalinization of the curricula (Horváth \& Probáld, 2003; Kardos, 2003). Only ten parochial secondary grammar schools were maintained from the churches' more than 4000 primary and roughly 100 secondary schools, which had to testify that the new regime "did not persecute religion" (Drahos, 1992, p. 49). Moreover, the entire framework of public administration underwent massive centralization. In 1950, the so-called council system was introduced in Hungary with 19 county-, 140 district- and roughly 3000 local-level councils in towns and villages, which actually had no local autonomy. Their exclusive task was to execute party-state decrees (Beluszky, 2003). In the words of János Beér, a key expert of public administration in the Stalinist period, "[local] councils are not the organs of local authorities, but local organs of the authority" (Beér, 1951, p. 595).

Small rural villages soon proved incompatible with the regime's notion of centralization and large-scale industrialization. They were seen as a feudal vestige, remnants of a feudal economic and social order that could not adapt to the planned modern future. In the words of János Kolta, who became a regional planner after the political turn in Baranya County, an area with an especially big number of small villages: 
Small settlements with an almost exclusively agricultural population are unable to keep pace with the rapid development that began in the political and social life of our country after the liberation [from the German occupation]; they make it harder to locate industrial facilities at suitable sites or create agricultural production units and in addition, they almost entirely prevent any form of equitable social, cultural, and administrative network from being established and sustained. (Kolta, 1979, p. 234)

Furthermore, the regime presented scattered farms as the locus of wealthy peasantsor kulaks, after the Soviet terminology — and thus justified a radical restructuring of thesesettlementsasadecisivestepagainst"reactionaries" and"counterrevolutionaries" (Hajdú, 1990/1991). This interpretation was in fact erroneous, given that wealthy peasants mainly lived in larger villages and rural towns, and scattered farm dwellers mostly belonged to the most impoverished stratum of rural society. The population of scattered farms also increased after the Soviet occupation, since the radical, communist land reform of 1945 created a vast number of extremely small plots, and motivated even more people to move to scattered farms, close to their newly gained land. In consequence, the number of inhabitants in such settlements increased to 900,000 in a country of 9 million (Beluszky, 2003).

The regime's firmly negative attitude towards small rural settlements resulted in severe regulations. The leadership soon considered settlements with less than 3000 inhabitants, constituting roughly one half of the Hungarian settlement network, as "uneconomical" to maintain (Beluszky, 2003). Hence, a 1949 government decree banned the construction of permanent flats or public buildings, including schools, on scattered farms, whereas a 1951 official plan for the urban network urged for a total ban on investment in these settlements (Hajdú, 1993). New education laws and decrees adhered to policy and did not provide any updated curriculum for scattered farm schools (Komlóssy, 1997).

The Communist regime tried to propagate these changes as necessary concomitants of modernization and thus referred to them with a strange mixture of technicized and biologized terms. Planners interpreted the envisaged mass demolition as a "process of remediation," "reconstruction of the settlement network," "dissolution of settlement density," and an "honorable, nice task for planners" in order to create an urban network that is "healthier and more capable of life" (Kolta, 1979). For ideological reasons, the Communist leadership, which perpetually claimed that its regime was the most "democratic" ever, also stressed the "voluntary" nature of the process. As Kolta said: "We shall guarantee in the entire process that it will be ... profoundly voluntary, administrative or political measures must not be taken" (p. 235). Yet, the subtext of this sentence's conclusion reveals the true link between plans and the actual punitive reality of strict decrees: “... however, the concentration of the population of small villages in larger ones should be accelerated by influencing people in a planned way" (p. 235). 


\section{Continuities Between Interwar and Postwar Modernism}

Although the Stalinist period brought about radical changes in the political, social, and economic domains, the dilemma about scattered farms it faced was not new in Hungarian academic thinking (Győri, 2009). Before Hungary joined World War II, a scientific debate took place between Ferenc Erdei, a sociologist and founder of the National Peasants' Party, part of the leftist opposition of the interwar government, and the urban geographer Tibor Mendöl, head of his department at the University of Budapest after 1940. On the basis of his research, Erdei argued that scattered farms and their central towns formed an optimal structure with units that complemented each other well. He also argued that this model of rural development should be promoted by planning in other parts of the country as well (Erdei, 1939). Mendöl, however, also highlighted the negative aspects, emphasizing that "it is ... easier to provide simple public infrastructure for a village ... than for a scattered farm fifty to a hundred times smaller" (Mendöl, 1939, p. 231). He therefore suggested that scattered farm centers and bigger villages should be developed instead. However, it is important to emphasize that Mendöl underscored these difficulties to provide a more sophisticated explanation of the issue than Erdei did and to explain why a migration from scattered farms to bigger villages was already taking place in some parts of the country. He considered any forced intervention to be intolerable. If people were not willing to move from scattered farms, he argued, one should not "get them into the habit of doing so" (Mendöl, 1939, p. 231).

It is one of the many controversies of the Communist period that Mendöl, who formulated these views, was as a bourgeois geographer permanently blocked after the political turn in his later academic career, whereas Erdei was appointed Minister for Agriculture and head of the so-called Scattered Farm Council in 1949, which the Stalinist regime established in order to find a scientific solution to the scattered farm problem. Moreover, Erdei now had to justify extremely antirural plans that were diametrically opposed to his interwar views, which the Communist regime promoted in accordance with expectations from Moscow (Györi, 2009; Győri \& Gyuris, 2015).

In fact, despite all the radical breaks after 1948, some of the trends that hallmarked the Stalinist period were not totally new and without precedent in Hungary. Evolving social and economic changes during the mid- and late-1930s and early 1940 s, including in the education system, were also motivated by international trends of modernization and centralization, and openly inspired by the increasing belief in state planning that developed in Western, Soviet communist, Fascist, and Nazi contexts as well. ${ }^{7}$ Hence, paradoxically, voluntarist Stalinist attempts at centralization and a more efficient spatial allocation of resources in some sense constituted more of a radical exaggeration of modernist notions that were already in play

\footnotetext{
${ }^{7}$ For some analysis of emerging state planning in Hungary in the 1930s and the international influences that fostered the process, see Lampland (2011) and Ungváry (2016). Lampland also reports on remarkable continuities of interwar and postwar (communist) state planning.
} 
(although in a remarkably different political framework) than a profound rupture with the recent past.

Finally, the grandiose plans of the Stalinist leadership largely failed to flourish. The Scattered Farm Council had severe difficulties with functioning from the very beginning, especially as its participants increasingly realized the impossibility of a rapid and successful implementation of anti-scattered-farm concepts (Hajdú, 1990/1991). The necessary material, financial, technical, etc. resources for such a program were also lacking, and Stalin's death in 1953 and the Hungarian Revolution in 1956 resulted in the Communist leadership revising many radical initiatives. Despite the plans that had been made, scattered farm schools mostly remained and the number of elementary schools in the country did not decline.

\section{Non-Stalinist Communism After 1956 and the "Rationalization" of Rural Schools}

After the Soviet troops crushed the 1956 Revolution, the Communist regime was re-established. The new party leader, János Kádár, enjoyed the support of the Soviet First Secretary Nikita Khruschev and took advantage of the somewhat increased flexibility in national political and economic decision-making within the Communist Bloc. He distanced the system from orthodox communist ideologies, and in the early 1960s introduced what later became known as "soft dictatorship" or "Goulash communism." Extremely radical political, economic, and social decisions of the Stalinist era as well as the very low material standard of living were seen as major reasons for the revolution. Therefore, official goals and the means of their implementation changed to some extent, and Marxist-Leninist orthodoxy was increasingly replaced by a technocratic attitude (Romsics, 2010). This had a visible impact on education and schools. In 1961, the government issued a new education law that (for the first time since the communist turn) gave new curricula to scattered farm schools, implicitly justifying their existence (Komlóssy, 1997).

Besides, the leadership wanted to promote "proportional development" by allocating more resources to formerly neglected areas. As early as 1958 an order of the Party stimulated industrial investments in the countryside, and official plans aimed to slow down the extreme concentration of the economy in Budapest (Hajdú, 1992). In several industrial sectors a ban was issued on increasing employment in production units in the capital city (Kondor, 2013). ${ }^{8}$ The Kádár regime carried out some

\footnotetext{
${ }^{8}$ Actual outcomes were controversial. Rural areas indeed gained numerous industrial workplaces, and Budapest's share of the national total decreased from 44.6\% in 1960 to $25.7 \%$ in 1980 (Bartke, 2003, pp. 124-129). Yet, this was just accelerating the upscaling of economic production in the capital city, which kept its extreme primacy in key economic and political branches (Meusburger, 1997) as well as corporate decision-making (Barta, 2002), and after further economic liberalization in the 1980s, became the main center of the so-called "second economy." As Nemes Nagy and Ruttkay (1989) revealed, 30.5\% of the economic labor cooperatives (gazdasági munkaközösségek (GMKs)), which were semiprivate forerunners of small private enterprises, were in Budapest.
} 
political decentralization as well. In 1970, it introduced a new council law that to some extent limited the nearly absolute dominance of national-level institutions and provided some competencies and resources to county-level councils as well. State funding for housing, for example, was now allotted to the counties, which could decide on their own how to distribute it among their localities (Illés, 2003).

These developments seemed to have a rather positive impact on rural areas. Yet, the system's inherent aim to maximize growth and reduce costs did not change, and the monolithic structure of the Party remained unchallenged. Hence, arguments for the "liquidation of inherited disproportionalities of the settlement network," as a 1963 official concept study of the Ministry of Construction put it, were still in play (Hajdú, 1992, p. 32). The 1971 National Concept of Settlement Network Development (Országos Telepuiléshálózat-fejlesztési Koncepció (OTK)), which created a spatially-oriented development plan for the country and served as the most influential such document for over 10 years, also sketched up a hierarchical structure of the urban network.

Although this gave impetus to regional centers in order to counterbalance Budapest, it also tended to provide decreasing resources to small settlements with fewer (or no) central functions. In light of agricultural collectivization, which had its decisive phase between 1958 and 1961 and caused many people to leave the countryside, and also because of the increasing need for additional labor force in cities and towns due to accelerated industrialization, the leadership calculated that the maintenance of small settlements would be inefficient in the long run. Since the regime believed that many rural schools would soon be unnecessary, it judged that the best chance for improve the standard of education lay in diverting pupils from ill-equipped institutions in small villages and scattered farms to well equipped town schools (Komlóssy, 1997). It propagated these notions of centralization in a technocratic language as "rationalization," to present the possible outcomes as positive and serving the interests of the entire country. ${ }^{9}$

Relocating resources from small rural settlements to larger centers was not only in the interest of the national leadership. The shortage economy also strongly motivated county-level leaders (Kornai, 1992), who now had some power over resource allocation in their county, to withdraw resources from their own periphery to stimulate faster growth in the main centers of the county, especially in the county capital. As a result, public services and infrastructure rapidly declined in many small villages during the 1970s (see Fig. 6.7) (Gyuris, 2014a). The total number of primary schools nationwide also dropped from above 6000 to nearly 4200 in a period of only 10 years (see Fig. 6.8).

Furthermore, as Kondor (2013) shows, the lobby force of large industrial enterprises and branch ministries was strong enough to slow down the planned relocation of industrial activities from Budapest to the countryside.

${ }^{9}$ Flyvbjerg (1998) and Basu (2004a, 2004b) explain in great detail the logic of similar discursive strategies in Western contexts. 


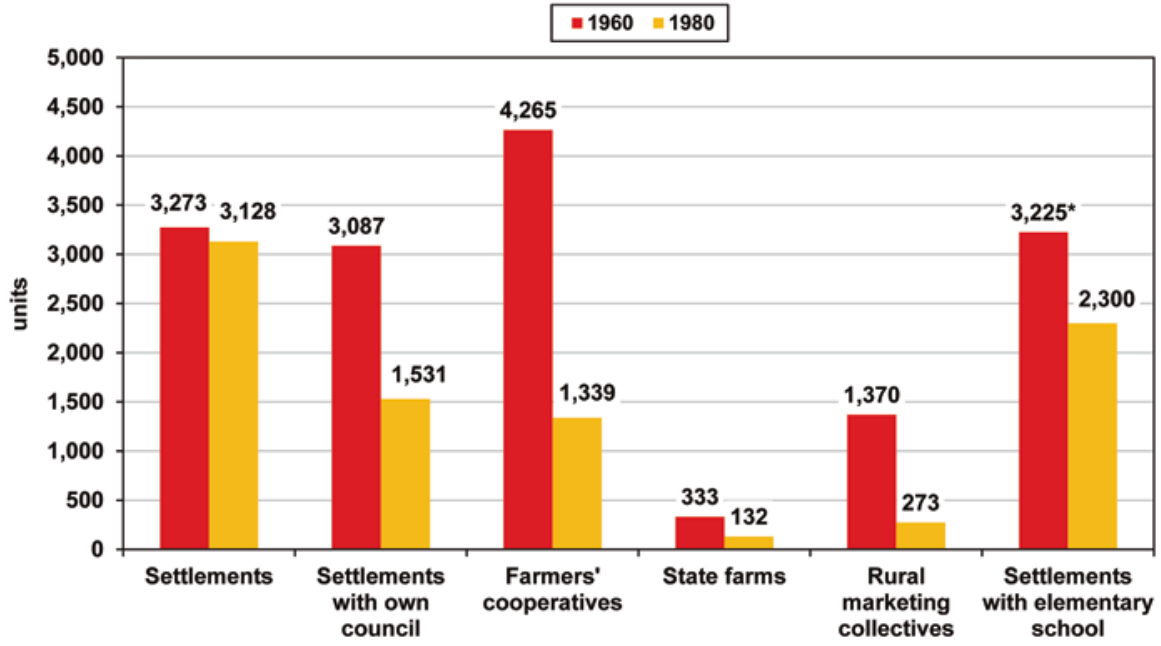

Fig. 6.7 Infrastructural changes in Hungarian settlement network due to "rationalizations" between 1960 and 1980. Adapted from Gyuris, 2014a, p. 308. Data from Nemes Nagy, J. (1987). Regionális folyamatok a nyolcvanas évek elsö felében [Regional processes in the first part of the 1980s]. Budapest: Országos Tervhivatal Tervgazdasági Intézet (p. 71). Reprinted with permission

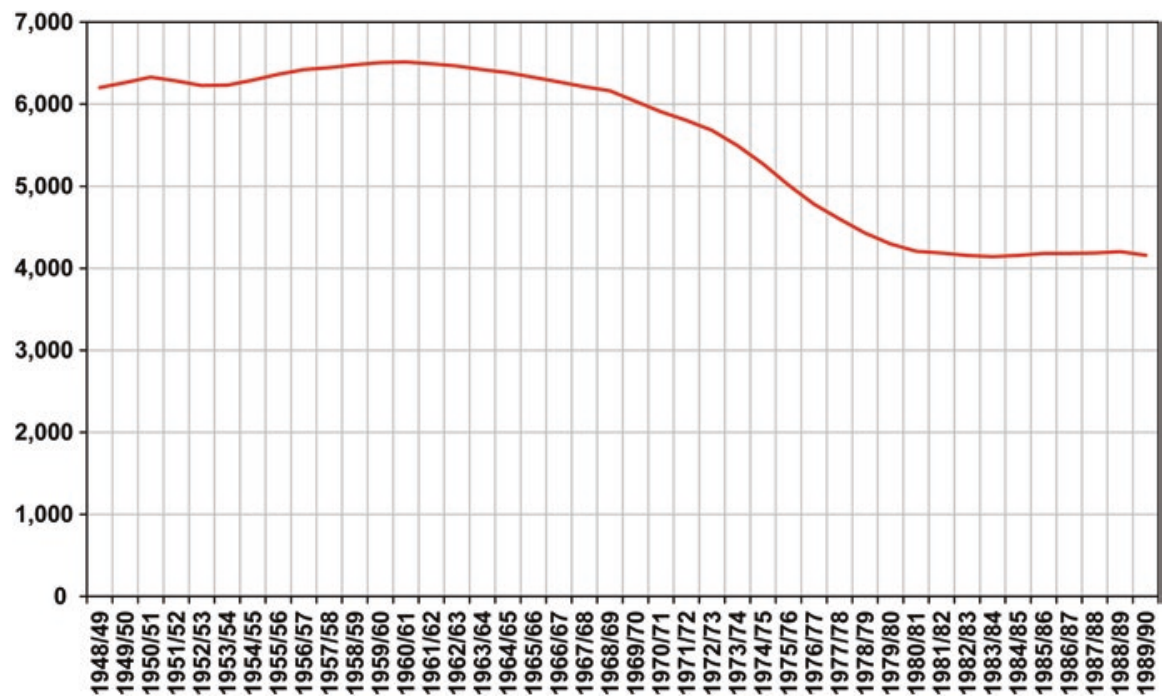

Fig. 6.8 Number of primary schools in Communist Hungary (1948/1949-1989/1990). Adapted from Gyuris, 2014b, p. 546. Data from Hungarian Central Statistical Office. (1996). Magyarország népessége és gazdasága: Múlt és jelen [The population and economy of Hungary: Past and present]. Budapest: KSH (pp. 229-230). Copyright by the Hungarian Central Statistical Office. Used under Creative Commons Attribution 3.0 Unported. Retrieved from https://www. thecommonsjournal.org/articles/10.18352/ijc.458/. Reprinted with permission 
Massive attempts to centralize infrastructure were in fact specific features of neither Hungarian communism nor the Communist Bloc (see chapter by Kučerová in this volume). As Bondi (1987), Meusburger and Kramer (1991), and Basu (2004a, 2004b) reveal, such considerations were rather typical in capitalist countries as well, which suggests that they were fundamentally rooted in modernism in general and not communism in peculiar. Yet the different political frameworks on both sides of the Iron Curtain resulted in remarkable variations in implementation. Whereas in Western countries mass protests and other organized forms of resistance often succeeded in at least slowing down centralization, in Communist regimes modernist plans could be carried out without considerable opposition. Schools were collective property, and local party leaders were appointed by their superiors, whom they loyally served in most cases instead of articulating the interests of local community. As Forray $(1990,1995)$ reveals, teachers themselves, with very few exceptions, also offered no resistance. Although they usually had some opportunity to formulate professional arguments in favor of sustaining small schools, they generally accepted the final decision of their superiors because they did not want to wreck their (or their family members') careers in a system where virtually all workplaces were provided or strongly controlled by the state..$^{10}$

The outcome was severe. Virtually all scattered farm schools were closed in the 1970s (Komlóssy, 1997), and many villages were left without schools as well. This accelerated the already massive outflow of population from these settlements, which was fueled not only by the pull factor of rapid industrialization and improving services in cities, but also by the firm push factor of agricultural collectivization and worsening access to even some basic infrastructure in small villages. Scattered farms thus lost 43.2\% of their inhabitants during the 1970s (Becsei, 1996, p. 48), and villages with fewer than 500 inhabitants in 1970 suffered a loss of $17.8 \%$ (based on data from Beluszky, 2003, p. 301). For villages with the same size, those which lost their schools had a significantly stronger decline than those where this institution survived (Nemes Nagy, 1982).

The conflicting interests and goals of the Communist regime therefore ended up subordinating the school system in general, and the management of small rural schools in particular, to the modernist goals of the system. Since these were aimed at promoting industrialization and urbanization, the Stalinist period brought about extremely radical plans for demolishing both small settlements and their schools, although these concepts remained largely unrealized due to a lack of resources. In the decades of post-Stalinist technocratic communism, the national party leadership's official attitude towards small settlements and small rural schools turned more tolerant. Yet the growth-oriented framework of the regime and the drive of more powerful urban centers for additional resource investment in a shortage economy, even at the cost of siphoning these resources from their own rural hinterland, resulted in an unprecedented decline of small rural schools during the 1960s and 1970s. This had a historically enduring impact on the school system, with small

\footnotetext{
${ }^{10}$ For a more detailed explanation of the lack of resistance, see Gyuris (2014b).
} 
rural schools generally remaining mired in their massively subordinate position from the 1970s until today.

\section{Conclusion}

The Hungarian education system in general, and rural schools in particular, had a turbulent history in both the interwar and communist periods. Their development trajectory reflected all significant shifts in the overall political, social, and economic framework of the country, and mirrored the manifold changes in dominant ideologies and the notion of spatial planning. After Hungary suffered immense territorial losses through the 1920 Trianon Peace Treaty, education became an even stronger cornerstone of nation-building than before. In a country that had surrendered two thirds of its territory and a vast amount of resources, schools were assigned a decisive role in defending the homeland. They now had to educate an internationally competitive elite and a mass of well-trained labor force in order to make Hungary economically competitive with other nations and to create millions of patriotic people supporting the revisionary goals of the political elite. Rural schools constituted a crucial means of this strategy, as the lack of sufficient education (including the problem of illiteracy) was the most pervasive in small rural settlements. Influenced by these considerations, the national political leadership backed large-scale school development projects, which thus enjoyed massive political and financial support.

Beyond these general features that were characteristic for the entire interwar period, however, the school system's development in some sense took a different path around the mid-1930s. In accordance with shifting international power relations after the Great Depression (including the Nazi takeover in Germany) and internal political changes in Hungary, which were not independent from the former process, the education system became increasingly centralized and dependent on state funding. It was increasingly focused on creating additional labor for the economy instead of increasing the intelligentsia, and more devoted to promoting social restructuring, including a conscious decrease of the share of Jews in specific occupations, instead of sustaining social stability.

The first few years after World War II witnessed multiparty governments trying to restore the education system after the damage of the war and carrying out several changes in institutional settings as well as regulatory frameworks, including ones that already been planned by interwar governments. The establishment of the communist dictatorship in 1948, however, opened the floor for extreme centralization in every sphere of life. Education became a means of creating "the new, socialist type of human" who is indoctrinated with Stalinist views and trained to provide manpower for large-scale industries. For its drive for maximizing material production and growth, the communist regime gave first priority to industrialization and urbanization. In contrast to egalitarian propaganda, this soon resulted in 
grandiose plans to demolish small settlements and their schools. Despite all these ruptures after 1948, however, radical attempts at centralization in the Stalinist period were rather an extreme exaggeration of modernist notions that had already been present in Hungarian politics and public administration since the 1930s than a complete break with the recent past.

Furthermore, just like the interwar period, the decades of communism were not homogeneous in Hungary in terms of education management. After the postStalinist shift and in accordance with decreasing orthodoxy in the entire Soviet Bloc, the emerging technocratic communist regime from the late 1950s onwards tried to counterbalance regional polarization and one-sided development of heavy industries. It now provided rural districts, small settlements, and their schools with more flexibility. The extreme level of centralization also decreased. Still, given the regime's inherent aim to maximize growth and the consequent pressure on every actor to find additional resources for investment in a shortage economy, villages now became massively exploited by regional urban centers. This resulted in a historically unprecedented decline of small schools in Hungary during the 1960s and 1970s. Therefore, although the technocratic communist regime made several changes in its economic and social policy compared to its Stalinist predecessor, it finally merely accelerated those processes that were rooted in the communist framework, and which had negative impacts on small settlements and schools that have lasted until today.

Acknowledgements The research reported in this chapter was supported by the ÚNKP-17-4 New National Excellence Program of the Ministry of Human Capacities (Hungary).

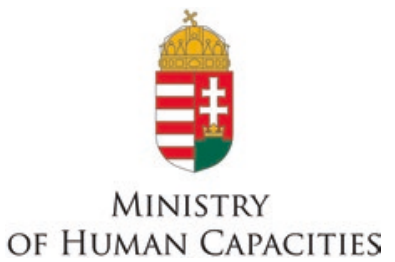

\section{References}

A Magyar Földrajzi Társaság szózata a világ Földrajzi Társaságaihoz [Manifesto of the Hungarian Geographical Society to the geographical societies of the world]. (1918). Földrajzi Közlemények, 46, 289-320.

Ablonczy, B. (2009). Bethlen István és Teleki Pál konzervativizmusa [The conservatism of István Bethlen and Pál Teleki]. In I. Romsics (Ed.), A magyar jobboldali hagyomány, 1900-1948 (pp. 167-185). Budapest, Hungary: Osiris.

Barta, G. (2002). A magyar ipar területi folyamatai 1945-2000 [Spatial processes of Hungarian industry 1945-2000]. Budapest, Hungary: Dialóg Campus. 
Bartke, I. (2003). A második világháború utáni gazdasági folyamatok [Economic trends after World War II]. In G. Perczel (Ed.), Magyarország társadalmi-gazdasági földrajza (pp. 103-147). Budapest, Hungary: ELTE Eötvös.

Basu, R. (2004a). The rationalization of neoliberalism in Ontario's public education system, 1995-2000. Geoforum, 35, 621-634. https://doi.org/10.1016/j.geoforum.2004.03.003

Basu, R. (2004b). A Flyvbjergian perspective on public elementary school closures in Toronto: A question of "rationality" or "power"? Environment and Planning C, 22, 423-451. https://doi. org/10.1068/c11r

Bateman, B. W. (2001). Make a righteous number: Social surveys, the men and religion forward movement, and quantification in American economics. History of Political Economy, 33 (Suppl. 1), 57-85. https://doi.org/10.1215/00182702-33-Suppl_1-57

Becsei, J. (1996). Városok és tanyák az Alföldön [Towns and scattered farms in the Great Plains]. Földrajzi Értesítö, 45, 35-53.

Beér, J. (1951). Helyi tanácsaink államhatalmi jellege [Power characteristics of local governments in Hungary]. Állam és Igazgatás, 3, 593-606.

Beluszky, P. (2003). Magyarország településföldrajza - Általános rész [The urban geography of Hungary]. Budapest, Hungary: Dialóg Campus.

Bethlen, I. (1933). Bethlen István gróf beszédei és írásai: Elsö kötet [Speeches and writings of Count István Bethlen: First Volume]. Budapest, Hungary: Genius.

Bondi, L. (1987). School closures and local politics: The negotiation of primary school rationalization in Manchester. Political Geography Quarterly, 6, 203-224. https://doi.org/10.1016/ S0260-9827(87)80001-0

Booth, C. (1902-1903). Life and labour of the people in London (3rd ed.). London: Macmillan.

Bullard, A. (2000). Exile to paradise: Savagery and civilization in Paris and the South Pacific, 1790-1900. Stanford, CA: Stanford University Press.

Butlin, R. A. (2009). Geographies of empire: European empires and colonies c. 1880-1960. Cambridge, UK: Cambridge University Press.

Cholnoky, J. (1912). Társaságunk Gazdasági Szakosztálya [The economic division of our society]. Földrajzi Közlemények, 40, 1-5. Retrieved from http://epa.oszk.hu/03000/03022/00005/pdf/ EPA03022_foldrajzi_kozlemenyek_1912_01_04_001-005.pdf

Conklin, A. L. (1997). A mission to civilize: The republican idea of empire in France and West Africa, 1895-1930. Stanford, CA: Stanford University Press.

Downing, J. A. (1988). Comparative perspectives on the development of the cognitive psychology of reading in the U.S.S.R. In J. A. Downing (Ed.), Cognitive psychology and reading in the U.S.S.R (pp. 1-27). Advances in psychology: Vol. 49. Amsterdam, the Netherlands: Elsevier.

Drahos, P. (1992). Katolikus iskolák az államosítás után [Catholic schools after the nationalization]. Education, 1, 46-64. Retrieved from http://epa.oszk.hu/01500/01551/00001/pdf/14.pdf

Dupin, C. (1826). Carte figurative de l'instruction populaire de la France [Map of basic education in France]. Retrieved from http://gallica.bnf.fr/ark:/12148/btv1b530830640

Erdei, F. (1939). Magyar város [Hungarian town]. Budapest, Hungary: Athenaeum.

Flyvbjerg, B. (1998). Rationality and power: Democracy in practice. Chicago: University of Chicago Press.

Fodor, F. (2006). A magyar földrajztudomány története [The history of Hungarian geography]. Budapest, Hungary: Geographical Research Institute, Hungarian Academy of Sciences.

Forray, K. (1990). Visszakörzetesítés? Aprófalvak harca az iskoláért [Reconcentration? Small villages' fight for schools]. A Falu, 6(2-3), 5-14.

Forray, K. (1995). Önkormányzatok és kisiskolák [Local governments and small schools]. Education, 4, 70-81. Retrieved from http://epa.oszk.hu/01500/01551/00072/pdf/EPA01551_ education_1995_1_070-081.pdf

Freytag, T., Jahnke, H., \& Kramer, C. (2015). Bildungsgeographie [Geography of education]. Darmstadt, Germany: Wissenschaftliche Buchgesellschaft. 
Glatz, F. (1990). Tudomány, kultúra, politika: Gróf Klebelsberg Kunó válogatott beszédei és írásai, 1917-1932 [Science, culture, politics: Count Kunó Klebelsberg's selected speeches and writings, 1917-1932]. Budapest, Hungary: Európa.

Győri, R. (2009). Tibor Mendöl. In H. Lorimer \& C. H. J. Withers (Eds.), Geographers (pp. 39-54). Bibliographical studies: Vol. 28. London: Continuum.

Györi, R., \& Gyuris, F. (2015). Knowledge and power in Sovietized Hungarian geography. In P. Meusburger, D. Gregory, \& L. Suarsana (Eds.), Geographies of knowledge and power (pp. 203-233). Knowledge and space: Vol. 7. Dordrecht, the Netherlands: Springer. https://doi. org/10.1007/978-94-017-9960-7_10

Gyuris, F. (2014a). The political discourse of spatial disparities: Geographical inequalities between science and propaganda. Cham, Switzerland: Springer. https://doi. org/10.1007/978-3-319-01508-8

Gyuris, F. (2014b). Basic education in communist Hungary: A commons approach. International Journal of the Commons, 8, 531-553. https://doi.org/10.18352/ijc.458

Hajdú, Z. (1990/1991). A Tanyai Tanács története: A “szocialista tanyapolitika” alapvetése és a tanyakérdés megoldásának radikális, voluntarisztikus kísérlete, 1949-1954 [A history of the scattered farms council: The fundaments of "socialist scattered farm policy" and the radical, voluntaristic experiment of solving the scattered farm issue, 1949-1954]. Alföldi Tanulmányok, $14,105-124$.

Hajdú, Z. (1992). Település- és településhálózat-fejlesztési politika Magyarországon az államszocializmus időszakában [Settlement and settlement network development policy in Hungary during the era of state socialism]. Földrajzi Közlemények, 40, 29-37.

Hajdú, Z. (1993). Település- és településhálózat-fejlesztési politika Magyarországon az államszocializmus időszakában [Settlement and settlement network development policy in Hungary during the era of state socialism]. In G. Enyedi (Ed.), Társadalmi-területi egyenlötlenségek Magyarországon (pp. 39-56). Budapest, Hungary: Közgazdasági és Jogi Könyvkiadó.

Havass, R. (1912). Magyar gazdasági és hatalmi törekvések a tengeren [Hungarian economic and political ambitions on the sea]. Földrajzi Közlemények, 40, 185-193. Retrieved from http://epa. oszk.hu/03000/03022/00009/pdf/EPA03022_foldrajzi_kozlemenyek_1912_08_185-193.pdf

Havass, R. (1913). Magyarország és a Balkán: Szerbia, Bulgária, Románia [Hungary and the Balkans: Serbia, Bulgaria, Romania]. Földrajzi Közlemények, 41, 153-216.

Hentschel, K., \& Hentschel, A. M. (1996). Physics and national socialism: An anthology of primary sources. Basel, Switzerland: Birkhäuser.

Hóman, B. (1938). Müvelödéspolitika [Cultural politics]. Budapest, Hungary: Hungarian Historical Society.

Hóman, B. (1942). Magyar sors - magyar hivatás: Mult és jövő [Hungarian fate - Hungarian calling: Past and future]. Budapest, Hungary: Athenaeum.

Horváth, G., \& Probáld, F. (2003). Geographical education in a region of transition—East Central Europe. International Research in Geographical and Environmental Education, 12, 139-147. https://doi.org/10.1080/10382040308667523

KSH (Hungarian Central Statistical Office). (1929). Az 1920. évi népszámlálás: Hatodik rész. [The 1920 Census: Vol. 6]. Budapest, Hungary: Athenaeum.

Hunt, A. (2002). Measuring morals: The beginnings of the Social Survey Movement in Canada, 1913-1917. Social History, 35, 171-194. Retrieved from http://hssh.journals.yorku.ca/index. $\mathrm{php} / \mathrm{hssh} /$ article/view/4488/3683

Huszti, J. (1942). Gróf Klebelsberg Kunó életmüve [Count Kunó Klebelsberg's oeuvre]. Budapest, Hungary: Hungarian Academy of Sciences.

Illés, I. (2003). Társadalmi szolgáltatások [Social services]. In G. Perczel (Ed.), Magyarország társadalmi-gazdasági földrajza (pp. 467-518). Budapest, Hungary: ELTE Eötvös Kiadó.

Joó, A. (2006). Az elemi népoktatás és a tanítóképzés reformja [The reform of elementary people's education and teacher training]. Iskolakultúra, 16, 3-23. Retrieved from http://epa.oszk. hu/00000/00011/00107/pdf/iskolakultura_EPA00011_2006_09_003-023.pdf 
Kardos, J. (2003). Fordulat a magyar iskolák életében: a Rákosi-időszak oktatáspolitikája [Turn in the life of Hungarian schools: Education policy in the Rákosi era]. Iskolakultúra, 13, 73-80. Retrieved from http://epa.oszk.hu/00000/00011/00072/pdf/iskolakultura_ EPA00011_2003_06_07_073-080.pdf

Kelemen, E. (2003). Oktatásügyi törvényhozásunk fordulópontjai a 19-20. században [Turning points in Hungarian legislation on education in the 19th and 20th centuries]. Iskolakulturra, 2003(2), 47-56. Retrieved from http://epa.oszk.hu/00000/00011/00068/pdf/iskolakultura EPA00011_2003_02_047-056.pdf

Kemény, G. (1916). Szerbia [Serbia]. Földrajzi Közlemények, 44, 65-108.

Klebelsberg, K. (1927). Gróf Klebelsberg Kunó beszédei, cikkei és törvényjavaslatai 1916-1926 [Speeches, articles and bills of Count Kunó Klebelsberg 1916-1926]. Budapest, Hungary: Athenaeum.

Klebelsberg, K. (1928). Neonacionalizmus [Neonationalism]. Budapest, Hungary: Athenaeum.

Klebelsberg, K. (1929). Küzdelmek könyve [The book of struggles]. Budapest, Hungary: Athenaeum.

Klebelsberg, K. (1930). Jöjjetek harmincas évek! [May you come, 1930s!]. Budapest, Hungary: Athenaeum.

Klebelsberg, K. (1931). Világválságban [In world crisis]. Budapest, Hungary: Athenaeum.

Kolta, J. (1979). Az aprófalvak helyzete és jövője Baranya megyében [The stand and future of small villages in Baranya county]. Földrajzi Közlemények, 27, 234-242.

Komlóssy, Á. (1997). Tanyai iskolák, tanyai tanítók [Scattered farm schools, scattered farm teachers]. Iskolakultúra, 5, 94-102.

Kondor, A. C. (2013). Iparpolitika és Budapest a Kádár-korszakban [Industrial policy and Budapest in the Kádár era]. Budapest, Hungary: Napvilág Kiadó.

Kornai, J. (1992). The socialist system: The political economy of communism. Oxford, UK: Clarendon.

Kovács, É. (2003). A magyar közoktatásügy története 1945 és 1956 között (A magyar közoktatáspolitika ideológiai változásai) [A history of education affairs in Hungary between 1945 and 1956: Ideological changes in Hungarian education policy] (Doctoral thesis). Budapest, Hungary: Faculty of Humanities, Eötvös Loránd University. Retrieved from http://www.history.mta.hu/munkatarsak/tezisek/hu_kovacseva.html

Kramer, C. (1993). Die Entwicklung des Standortnetzes von Grundschulen im ländlichen Raum: Vorarlberg und Baden-Württemberg im Vergleich [Development of the location network of elementary schools in rural space: Vorarlberg and Baden-Württemberg in comparison]. Heidelberger Geographische Arbeiten: Vol. 93. Heidelberg, Germany: Selbstverlag des Geographischen Instituts der Universität Heidelberg.

Lampland, M. (2011). The technopolitical lineage of state planning in Hungary, 1930-1956. In G. Hecht (Ed.), Entangled geographies: Empire and technopolitics in the global Cold War (pp. 155-184). Cambridge, MA: MIT Press.

Livingstone, D. N. (2002). Science, space, and hermeneutics. Hettner-Lecture: Vol. 5. Heidelberg, Germany: Department of Geography, Heidelberg University.

Livingstone, D. N. (2011). Environmental determinism. In J. A. Agnew \& D. N. Livingstone (Eds.), The SAGE handbook of geographical knowledge (pp. 368-380). London: Sage.

Mendöl, T. (1939). Néhány szó az alföldi város kérdéséhez [Some words to the question of Great Plain towns]. Földrajzi Közlemények, 67, 217-232.

Meusburger, P. (1997). Spatial and social inequality in communist countries and in the first period of the transformation process to a market economy: The example of Hungary. Geographical Review Japan, 70(Ser. B), 126-143. https://doi.org/10.4157/grj1984b.70.126

Meusburger, P. (1998). Bildungsgeographie [Geography of education]. Heidelberg, Germany: Spektrum.

Meusburger, P. (2015). Education, geography of. In J. D. Wright (Ed.), International encyclopedia of the social \& behavioral sciences: Vol. 7 (2nd ed., pp. 165-171). Oxford, UK: Elsevier. 
Meusburger, P., \& Kramer, C. (1991). Die Entwicklung des Vorarlberger Volksschulwesens zwischen 1948 und 1987-im Vergleich zum gesamtösterreichischen Trend [The development of primary education in Vorarlberg between 1948 and 1987-in comparison with national trends in Austria]. Österreich in Geschichte und Literatur mit Geographie, 35, 185-201.

Mills, C. W. (1956). The power elite. New York: Oxford University Press.

Musgrave, R. A. (1957). A multiple theory of budget determination. Finanzarchiv, 17, 333-343.

Nagy, P. T. (2004). Az 1938-as tanítóképzési reform [The 1938 reform of teacher training]. Magyar Pedagógia, 104, 251-262. Retrieved from http://www.magyarpedagogia.hu/document/Nagy_ MP1043.pdf

Nagy, P. T. (2005). Az állami befolyás növekedése a magyarországi oktatáspolitikában 1867-1945 [Increasing state influence in education affairs in Hungary, 1867-1945]. Iskolakultúra, 2005(6-7), 3-229. Retrieved from http://epa.oszk.hu/00000/00011/00094/pdf/ tan_vita2005-6-7.pdf

Nagy, P. T. (2011). A növekvö állam árnyékában: Oktatás, politika 1867-1945 [In the shadow of the growing state: Education, politics 1867-1945]. Budapest, Hungary: Gondolat.

Nemes Nagy, J. (1982). Az iskolakörzetesítések hatása az aprófalvak népesség-fejlődésére [The implication of school regionalizations on population development in small villages]. Területi Statisztika, 32, 104-109.

Nemes Nagy, J., \& Ruttkay, É. (1989). A második gazdaság földrajza [Geography of the second economy]. Budapest, Hungary: Institute of Economic Planning, National Planning Bureau.

Paksa, R. (2014). A numerus clausus és módosítása [The numerus clausus and its modification]. In B. Ablonczy (Ed.), Gróf Bethlen István és kora (pp. 137-157). Budapest, Hungary: Osiris.

Pornói, I. (1995). Az 1920-as évek népoktatása és a nyolcosztályos népiskola Magyarországon [People's education in the 1920s and the eight-class people's school in Hungary]. Magyar Pedagógia, 95, 315-331. Retrieved from http://www.magyarpedagogia.hu/document/Pornoi_ MP9534.pdf

Romsics, I. (2007). A trianoni békeszerződés [The Trianon Peace Treaty]. Budapest, Hungary: Osiris.

Romsics, I. (2010). Magyarország története a XX. században [A history of Hungary in the $20^{\text {th }}$ century]. Budapest, Hungary: Osiris.

Sáska, G. (2005). A társadalmi egyenlőség antikapitalista és demokrácia-ellenes képzete a XX. századi pedagógiai ideológiákban [The anti-capitalist and anti-democratic idea of social equality in $20^{\text {th }}$ century pedagogical ideologies]. Magyar Pedagógia, 105, 83-99. Retrieved from http://www.magyarpedagogia.hu/document/Saska_MP1051.pdf

Schmidt-Ott, F. (1952). Erlebtes und Erstrebtes 1860-1950 [Things lived and aspired to, 1860-1950]. Wiesbaden, Germany: Franz Steiner.

Schriewer, J., \& Nóvoa, A. (2001). Education, history of. In N. J. Smelser \& P. B. Baltes (Eds.), International encyclopedia of the social \& behavioral sciences: Vol. 6 (pp. 4217-4223). Oxford, UK: Elsevier.

Schroeder-Gudehus, B. (2014). Les scientifiques et la paix: La communauté scientifique internationale au cours des anées 20 [Scientists and peace: The international scientific community during the 1920s]. Montréal, Canada: Les Presses de l'Université de Montréal.

Szabó, A. (2007). A trianoni Magyarország közoktatási infrastruktúrája [The public education infrastructure in post-Trianon Hungary]. Földrajzi Közlemények, 131, 39-53.

Szabó, D. (1937). A szellemi együttmüködés célja, tartalma, határai [The goal, content, and limits of mental cooperation]. Budapest, Hungary: Ludas Mátyás.

Teleki, P. (1936). A gazdasági élet földrajzi alapjai I-II [The geographical fundaments of economic life I-II]. Budapest, Hungary: Centrum.

Titze, H. (2006). Bildungskrisen und Selbstorganisation der Kultur: Zur Eigendynamik von Bildungsprozessen in der Moderne [Crises in education and the self-organization of culture: About the momentum of modern-day education processes]. In K. Kempter \& P. Meusburger (Eds.), Bildung und Wissensgesellschaft (pp. 163-208). Berlin, Germany: Springer. https://doi. org/10.1007/3-540-29517-8_8 
Treaty of Peace with Germany (Treaty of Versailles). (1919). Retrieved from http://net.lib.byu. edu/ rdh7/wwi/versailles.html

Ujváry, G. (2006). Carl Heinrich Becker feljegyzése 1926. május-júniusi magyarországi látogatásáról [Carl Heinrich Becker's note on his visit to Hungary in May-June 1926]. In G. Ujváry (Ed.), Lymbus. Magyarságtudományi közlemények (pp. 279-305). Budapest, Hungary: Balassi Bálint Institute; National Archives of Hungary; International Association for Hungarian Studies; National Széchényi Library. Retrieved from http://epa.oszk.hu/01500/01500/00004/ pdf/00004_274.pdf

Ujváry, G. (2009). Klebelsberg Kuno és Hóman Bálint kultúrpolitikája [The cultural politics of Kuno Klebelsberg and Bálint Hóman]. In I. Romsics (Ed.), A magyar jobboldali hagyomány, 1900-1948 (pp. 377-413). Budapest, Hungary: Osiris.

Ujváry, G. (2014). Bethlen István és Klebelsberg Kuno kapcsolata [The relation between István Bethlen and Kuno Klebelsberg]. In B. Ablonczy (Ed.), Gróf Bethlen István és kora (pp. 121-136). Budapest, Hungary: Osiris.

UNESCO. (1953). Progress of literacy in various countries: A preliminary statistical study of available census data since 1900. Paris: United Nations.

Ungváry, K. (2016). A Horthy-rendszer és antiszemitizmusának mérlege: Diszkrimináció és társadalompolitika Magyarországon 1919-1944 [The balance of the Horthy regime and its anti-Semitism: Discrimination and social policy in Hungary 1919-1944]. Budapest, Hungary: Jelenkor.

Zátonyi, S. (2006). Hatvan éves az általános iskola [Elementary school is sixty years old]. Iskolakultúra, 16, 49-58.

Open Access This chapter is licensed under the terms of the Creative Commons Attribution 4.0 International License (http://creativecommons.org/licenses/by/4.0/), which permits use, sharing, adaptation, distribution and reproduction in any medium or format, as long as you give appropriate credit to the original author(s) and the source, provide a link to the Creative Commons license and indicate if changes were made.

The images or other third party material in this chapter are included in the chapter's Creative Commons license, unless indicated otherwise in a credit line to the material. If material is not included in the chapter's Creative Commons license and your intended use is not permitted by statutory regulation or exceeds the permitted use, you will need to obtain permission directly from the copyright holder.

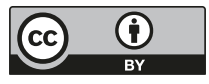

